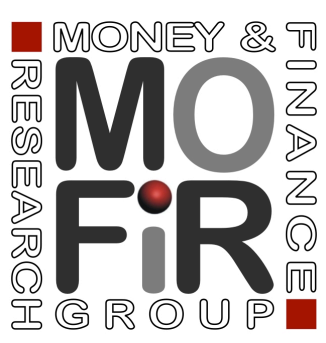

\title{
What PiketTy SAID IN "CAPITAL IN THE TWENTY-FIRST CENTURY" AND HOW ECONOMISTS REACTED
}

Riccardo De Bonis

Working paper no. 130

November 2016 


\title{
What Piketty said in Capital in the Twenty-first Century and how economists reacted
}

Riccardo De Bonis*

October 2016

\begin{abstract}
This work rehearses the main themes of Piketty's book and summarizes the debate it triggered. The paper dwells on the rise in the ratio of household wealth to GDP in the rich countries since the 1980s and the role played by the build-up of saving and variations in house and financial asset prices; on the various justifications put forward for the increasing income and wealth inequality that has accompanied the rise in the wealth/income ratio, especially in the US and Britain; on the relationship between the rate of return on capital and the economic growth rate; on the ties between rising income inequality and the financial crisis of 2007-08; on the feasibility of Piketty's proposals for higher taxation of top incomes and a progressive global tax on net household wealth; and on the progress that has been made in the US and Europe in exchanging information on citizens' income and foreign assets.
\end{abstract}

Keywords: ratio household wealth/GDP; distribution of income and wealth; taxation; welfare State. JEL codes: C80; D14; D31; D91; E62; H26.

*Bank of Italy, Directorate General for Economics, Statistics and Research. This is a revised version or the article published in Italian in "Rivista di storia economica", December 2015. Andrea Brandolini and Alessandra Sanelli provided useful comments on an earlier draft. We thank very much Roger Meservey for his help with translation. The views and opinions set forth here are my own and do not implicate the Bank of Italy. 


\section{Introduction}

Piketty’s “Capital in the Twenty-first Century” has sold more than one-and-a-half million copies, been translated into over thirty languages, and triggered intense polemics. This essay is divided into two parts. First is a summary limited to less than 2 per cent as long as the English edition. The second part discusses the main issues that Piketty raises and traces the debate that it has triggered.

\section{What does Piketty say?}

First, let us clear up a possible linguistic misunderstanding: What Piketty calls "capital” - in an evident allusion to Marx - is what we call "household wealth,” i.e. the sum of financial and real wealth net of debt. In the economic growth literature, capital is obtained as the sum of the flow of investment and the pre-existing capital stock. Piketty, instead, measures capital as the financial and real assets of households or individuals (see also Piketty and Zucman, 2014). To avoid repetition and keep from betraying the spirit of Piketty’s work, we use wealth and capital as synonyms. He himself uses "private wealth” as a synonym for capital.

Capital in the Twenty-first Century consists of an introduction and four parts. The introduction and Part One set out the basic messages and describe the toolkit used. Part Two is given over to wealth and its ratio to income. Part Three analyzes the distribution of income and wealth. Part Four sets out the author's economic policy proposals.

1.1. Income and capital. Piketty begins by recalling the central role played by considerations of income distribution in the works of Malthus, Ricardo and Marx. He underscores that their pessimistic theses - in particular the falling rate of profit in Marx - have proven to be wrong. For a long time the issue was neglected. The distribution of income came back into fashion in 1955 with Simon Kuznets' talk at the annual meeting of the American Economic Association and the introduction of the Kuznets curve. He argued that income inequality follows a bell curve: it increases in the early stages of capitalistic accumulation - when not everyone can appropriate innovations - and then diminishes thanks to economic growth. This conclusion was based on his 
1953 book on the income distribution in the United States from 1913 to 1948, a period during which income inequality did in fact diminish.

Piketty acknowledges that Kuznets was more prudent in his books than in his articles. But on the other hand he attacks Kuznets for the superficial conclusions set forth in the 1955 piece. The diminution in inequality between 1919 and 1945 was actually due to the world wars and the consequent shocks, especially to very large fortunes. Piketty rejects the thesis that the distribution of income depends on technological factors and argues instead that it is determined by social and political forces. The introduction anticipates two of the book’s main findings.

1) The distribution of income has now become highly unequal again. At the turn of the $20^{\text {th }}$ century the richest 10 per cent of the American population earned 45-50 per cent of total income. In the 1950s this had fallen to 35 per cent, but today we are back to the levels of the early 1900s. He repeats that inequality is not an evil in and of itself. His purpose is to study whether inequality is justified, whether there are reasons that make it acceptable.

2) The ratio of wealth to GDP has risen in all the rich countries: from 2-3 times in 1950 to 4-6 times today, about the same as in the Gilded Age.

Piketty introduces the reader to national accounting concepts and presents what he considers the first fundamental law of capitalism, an identity whereby the share of income that capital appropriates $(\alpha)$ depends on the return to capital $(r)$ and the ratio of wealth to income $(\beta)$ :

$$
\alpha=r \times \beta .
$$

In explaining the rise in $\beta$, the capital/income ratio, Piketty says that the decisive factor is the slow rise in the denominator. On this point he is pessimistic: GDP growth will slow further because both population growth and per capita GDP growth will diminish.

1.2. The dynamic of the capital/income ratio. Piketty begins by discussing France and the United Kingdom, the two countries for which the longest time series are available. Since 1700 the capital/income ratio has followed a U-curve, and today it is at the same level as three centuries ago. In the meantime, however, wealth has undergone a metamorphosis, with a sharp relative decline in landed wealth, replaced by the value of houses. "Net foreign assets," i.e. the difference between assets and liabilities outside the country, have always been minor, in spite of the two powers' colonial empires. Since the 1980s privatizations have reduced public assets and increased private wealth in both countries.

Between Germany and the United States, the dynamic of the wealth/income ratio has differed. Germany has always had less private wealth than France or Britain, ever since the late nineteenth 
century. And despite the high German household saving rate since World War II, this remains the case today, owing to two factors. First, house prices in Germany are lower than in France and Britain, in part as a consequence of national reunification after 1989, which put low-value houses on the market. Moreover, Germany did not have the housing price bubble that characterized many industrial countries from the first 2000s to the eruption of the global financial crisis. Second, the value of corporate equity in Germany is low, the effect of "Rhenish capitalism". The German governance model, with trade unions, regional governments and consumer organizations all having representatives on corporate boards of directors, implies lower market valuation of shares than in the US or British "shareholder model”. Indeed, the ratio of stock market capitalization to GDP is in Germany smaller than that in the UK and France.

By comparison with France and the UK, wealth has always been lower in the US, where land has historically been cheap, given its overabundance, as have houses. America's net foreign assets too have always been negligible, as the country was never a colonial power. Wealth is lower in the US than in Europe also, Piketty argues, because the persistence of slavery for a longer period provided less incentive for the accumulation of capital.

Since 1870 the capital/income ratio in Europe has always been higher than in the United States, except between 1920 and 1980. In Germany, France and Britain, between 1915 and 1950 wealth was destroyed by war, the reduction in net foreign assets, and low saving. The history of this period, says Piketty, is "the history of European suicide and in particular of the euthanasia of European capitalists.” After 1950 private wealth did not expand greatly, reflecting the slow rise in asset prices in economies characterized, until 1980, by strong public intervention. Private wealth in these rich countries amounted to between 2 and 3.5 times GDP in 1970. Since 1980 the ratio has risen especially fast in Europe, where it is now about 6 times, compared with 4 times in the United States. What forces explain these developments? According to Piketty, the second fundamental law of capitalism is:

$$
\beta=s / g
$$

where $\beta$ is the ratio of capital to income, $s$ is the saving rate and $g$ the GDP growth rate. The low level of $g$, owing above all to low population growth in the advanced countries, explains why $\beta$ has risen. The rise in $\beta$, net of short-term fluctuations, is also related to the privatization of public assets starting in the 1970s and to the jump in house and share prices, which had moved only slowly in the decades following 1945 because of rent control and the extension of financial regulation.

In Piketty's opinion, the increase in saving was more important than the rise in asset prices in explaining the rise in $\beta$. Since the 1970s there has been a "financialization" of the economy and a 
new patrimonial capitalism has emerged. Piketty presents a series of simulations of the ratio of wealth to income, on whose basis $\beta$ could be higher than 7 by the end of the twenty-first century.

The author rebuts the thesis of stability of the income shares of labour and capital, which was taken to be incontrovertible between 1950 and 1970 but has been criticized in recent years, recognizing that labour's share has declined. The share of income going to capital $-\alpha$ - increased between 1970 and 2010, which explains why the wealth/income ratio too has risen. In stagnating economies, the capital accumulated in the past looms larger. This tendency could perfectly well continue and will not necessarily lead to a collapse in the return to capital. The most likely hypothesis is that the decline in the return will be more smaller than the rise in the wealth/income ratio. So the share of national income going to capital will increase further.

In short, a rise in the capital/GDP ratio produces an increase in $\alpha$; the rise in $\alpha$ drives up $\beta$, because part of the income going to capital is saved and thus added to the capital.

\subsection{The structure of inequality.}

1.3.1 Preliminaries. The bulk of the book is devoted to inequality, which Piketty separates into in three forms: (i) the distribution of wealth; (ii) the distribution of income from work, and (iii) the distribution of total income, including income from capital. Inequality is discussed with respect to three classes: the wealthiest 10 per cent (the upper class, itself divided into the top 1 per cent - the “dominant class" - and the remaining 9 per cent), the next 40 per cent (the middle class), and the poorest 50 per cent (the lower class).

Wealth has always been very unequally distributed. Today, the bottom 50 per cent of the population in the advanced countries owns practically nothing; at most, as in Scandinavia, this group may hold 10 per cent of total wealth. The United States displays the most pronounced inequality. The wealthiest 10 per cent of Americans possess 70 per cent of the total wealth. The middle class has 25 per cent and the lower class just 5 per cent. European countries are less unequal, with respective shares of 60, 35 and 5 per cent. Everywhere, as individual income rises the relative importance of real estate (home ownership) in wealth declines and that of financial assets increases. A century ago, around 1900, wealth was much more concentrated than it is today: there was no “patrimonial middle class,” as Piketty calls it.

The distribution of labor income is less unequal than that of wealth. ${ }^{1}$ The distribution of total income is somewhere in the middle: less unequal than that of wealth but more than that of labor

\footnotetext{
${ }^{1}$ In the US, the most unequal of the countries studied, the upper class earns 35 per cent of total labor income, the middle class 40 per cent and the lower class the remaining 25 per cent. Here again, Europe is less unequal, with shares of 25,45 and 30 per cent.
} 
income, owing to the incidence of capital income. Since capital income averages 25 per cent of total income, the overall income distribution is closer to that of labor income than to that of wealth.

The key point is the explanation, or justification, and not the extent, of income inequality. An unequal society may be of two alternative types: a society of rentiers or a society of supermanagers. In a rentier society, income inequality is bound up with the concentration of wealth, with high capital income and inheritance. In a society of supermanagers, instead, inequality derives from high labor incomes. Here, Piketty anticipates the finding that the US takes after this latter model, with an inequality of labor income possibly unparalleled anywhere in the world.

1.3.2 Income distribution. Piketty next examines the evolution of total income inequality since 1800 more closely, mainly comparing developments in France and the United States. Starting from the high levels of the nineteenth century, French inequality diminished between 1914 and 1945 as a consequence of the decreased relative importance of the rentier class and the collapse of top capital incomes. There was no reduction in salary inequality. After World War II the rentiers were progressively replaced by managers, with high labor incomes. Since 1980 inequality has increased again in France, with the emergence in the 1980s of the very high salaries earned by top executives in the large corporations and banks. Of the wealthiest 10 per cent of the population, nine-tenths have chiefly labor income, one-tenth chiefly capital income.

The case of the United States is different. In 1900-1910 income was less unequally distributed than in France (or Britain), because the wealth/income ratio was lower and because wealth inequality was less extreme. The United States appeared as the land of opportunity, truly a New World, against the inequalities of the Old. Income inequality increased in America after World War I, but the real explosion of inequality did not come until after 1980. The share of income going to the wealthiest 10 per cent, and especially the top 1 per cent, increased. The main factor in the increasing inequality in total income was not capital gains but the emergence of supersalaries. The richest of all are the supermanagers - not athletes or artists - and Piketty maintains that increasing inequality was at the root of the financial crisis.

Piketty cites the thesis that inequality in labor income stems from the "race" between education and technology (Goldin and Katz, 2010). The idea is that the individual's earnings are determined by his or her marginal productivity, which in turn depends on skills, affected above all by education. During periods of technological progress, in the labour market the demand for highly skilled workers increases. If the education system is unable to meet this demand, low-skilled workers will be relegated to inferior positions. After 1980, in the United States the wage gap between college and high-school graduates widened; and the number of university graduates ceased 
growing, reversing the tendency that had marked the entire century to that point. Goldin and Katz conclude that growing US wage inequality stems from the failure to invest in higher education. Too many people fail to get adequate training because their families are unable to sustain the costs of education.

Piketty rejects the notion that education should be considered mainly as a tool for increasing the individual's earnings. Like health, in his view, education is a value in itself. He nevertheless accepts the thesis that in the long run education and technology are major determinants of wage levels. In the short run, however, the thesis that wages depend on education is not convincing, because inequality actually depends on institutional factors, such as the minimum wage laws. The US introduced the minimum wage in 1933, nearly twenty years before France. Higher than in France until 1985, from the Reagan years onward the US minimum wage declined and in 2013 it was a third lower than in France (\$7.30 as against $€ 9.40$ at purchasing power parity). Labour market rules and institutions remain crucial determinants of wage distribution.

If the bottom part of the income distribution was affected by minimum wage developments, other mechanisms underlie the changes in the income share going to the top 1 per cent. It has increased since the 1970s in all the Anglo-Saxon countries, but more sharply in the United States than in Britain, Canada or Australia. By contrast, this group’s share has not increased in France, Germany, Sweden or Japan, and the same goes for Italy and Spain. In 2010, the richest 1 per cent of the population took 17 per cent of total labor income in the US and 15 per cent in the UK, showing a sharp increase since 1970. In continental Europe these percentages are lower, nor have they changed significantly over the period. Also considering the top 0.1 per cent, their income share is higher in the US and the UK than in Canada and Australia, and especially the European countries.

In Piketty's view, these differences between the US, the other Anglo-Saxon countries, and Europe (and Japan) cannot be explained by trends in marginal productivity, technology or education, which are quite similar among these countries. Marginal productivity cannot explain the earnings boom for the top 1 or 0.1 per cent. What is more, at the turn of the twentieth century European societies were more unequal than the US, and it is only since 1970 that the positions have switched. There are also differences between European countries. Since 1950 the top 1 per cent in Germany have received a higher income share than in other European countries (and Japan). Income inequality appears to have sharpened since 1980 in the emerging economies as well (though one must beware of the poorer quality of statistics in these countries) but is still less than in the US.

More than by individual skills, the high salaries of Anglo-Saxon managers are determined by corporate hierarchies and compensation committees: in this realm, Adam Smith's "invisible hand” 
does not exist. Since 1970 social norms have accepted very high salaries in the US and the other Anglo-Saxon countries, while the cultural climate in the rest of Europe is different. Where British and American public opinion accepts these multimillion-dollar salaries, in Sweden, Germany, France, Japan and Italy such incomes are regarded as suspect. Examining corporate financial statements, it is hard to find a correlation between corporate performance and executive pay. Bertrand and Mullainathan (2001) find that in American corporations CEOs' compensation, more than rewarding corporate performance, is “pay for luck”.

1.3.2. Wealth distribution. Now let us look at the distribution of wealth. In France the share held by the top 1 or 10 per cent of the population declined between 1910 and 1970, and has risen slightly since. Similar patterns can be seen in the United Kingdom and Sweden. Everywhere, the concentration of wealth is lower now than it was in the Belle Epoque.

Again, US history is different. In 1810 the distribution of wealth in America was less unequal than in Europe. Inequality intensified in the course of the nineteenth century, but even at the end of the Gilded Age in 1910 it was still less than in Europe. After 1945 US inequality increased, and since 1970 it has been greater than in Europe, whether our gauge is the top 1 or 10 per cent.

What are the determinants of these patterns in wealth distribution? Based on estimates running back hundreds of years, Piketty shows that the pre-tax return to capital has always been higher than the rate of growth of income. And even the after-tax yield on capital has always outstripped the growth rate, except in the twentieth century. Piketty predicts that in the twenty-first and twentysecond centuries the after-tax return to capital will overtake the growth rate again. The fact that capital returns have almost always been higher than the rate of growth in income has a number of causes: precautionary saving, the importance ascribed to wealth as such, the features of public pension systems, and households' choices under the influence of institutional and cultural factors.

Wealth inequality has not returned to the levels of the Belle Epoque because the wars brought the massive destruction of wealth, but also thanks to the decisive role of capital taxation. Until World War I taxes on wealth or corporate profits were minimal or non-existent. Inheritance taxes too, sometimes progressive, also became significant only after the war, helping to lower the share of the wealthiest 1 per cent. In Piketty's account, there is nothing automatic about these tendencies, which have kept wealth inequality from returning to its earlier level. In the future the distribution could become more unequal, even return to Belle Epoque levels.

Piketty inquires into the role of merit and inheritance, focusing mainly on France, which has the best statistics. He wonders whether we can be sure that since the nineteenth century work has really gained in importance relative to inheritance. The concentration of wealth is lower now than in the 
past. Even though the poorest 50 per cent of the population still owns next to nothing, a patrimonial or propertied middle class has arisen, owning between a quarter and a third of the total wealth of the nation.

The question, however, is whether the different concentration of wealth is determined by saving, by inheritance, or by increasing longevity. Since 1960 inheritances have increased in France, though this flow of wealth remains smaller than in the nineteenth century. The baby boomers of the 1950s could not count on inheriting any large fortunes, given the destruction of wealth in two world wars. This induced the optimistic conclusion that such fortunes were bound to disappear. Instead, inheritances have remained important, unaffected by the fact that people are living longer and so coming into wealth later in life. Parents have understood the need to make gifts to their children while they are still young; this has increased the importance of accumulated wealth.

Simulations show that the flow of bequests will continue to expand this century. We have gone back to a dynastic society, in which 10 per cent of the population has 50 or 60 per cent of total wealth. There are people who thanks to enormous wealth have no need for dissaving or asset disposal. The thesis that an elderly population will consume the wealth accumulated and thus no longer bequeath wealth to their heirs is false.

The share of bequests in total wealth is regaining the levels of the nineteenth century. For income from inheritance to prevail over labor income in a society, two conditions must obtain: i) wealth, and its bequest component, must be large; and ii) inherited wealth must be highly concentrated. In Piketty's view, we risk finding ourselves in a world marked by two ugly features of the past: severe inequality in inherited wealth and severe inequality in salaries, justified in terms of merit and productivity. French society is dominated by "petits rentiers": we have gone from a society of a few big rentiers to one of many small rentiers. Piketty examines other countries as well, showing that the flow of bequests also forms a U-shaped curve in the United Kingdom and Germany. There are no data on inheritance flows for Italy or Spain, and surveys of the United States are deemed unreliable due to underreporting.

Furthermore, the rich also obtain higher yields on their wealth than others. Forbes Magazine estimates that the number of billionaires in the world rose from 140 in 1987 to 1,400 in 2013 and their assets expanded from \$300 billion to \$5.4 trillion. World wealth grew somewhat more than income, but the wealth of the richest individuals grew much more. Inherited wealth accounts for more than half of the world's largest fortunes. Inflation does not lower the return to capital: if consumer prices rise at a rate of 2 per cent, asset prices will rise at about the same rate. The main effect of inflation is redistributive: it makes the distribution of wealth more unequal. 
Simulations indicate that by the end of the century Asia will control half of the world's wealth, much more than in 1950. At the same time, however, Piketty does not believe that China will be the "master of the world". The Chinese saving rate will decline in response to the need to increase consumption. Moreover, the world's wealth is concentrated in the rich countries. The net wealth of European households is around $€ 70$ trillion, while Chinese sovereign funds plus the foreign exchange reserves of the People’s Bank total just €3 trillion. Zucman (2014) has shown that the developed countries are far wealthier than appears from the official statistics. Individuals hold assets equal to 10 per cent of world GDP in tax havens, and at least three fourths of these assets are traceable to persons resident in the rich countries.

1.4 Regulating capital in the twenty-first century. Given that inequality is growing again, what measures should be taken to reduce it? Part 4 is given over to Piketty's economic policy proposals, that touch three themes: the welfare State, taxation and public debt.

1.4.1 On the welfare State. Piketty recounts the development of the welfare state, or social state, from its first beginnings around the turn of the twentieth century and discusses its future prospects. Up to 1910, in the main countries tax revenues never exceeded 10 per cent of GDP. Today they range from 30 per cent in the US to 55 per cent in Sweden. The rise took place between 1920 and 1980, when the share stabilized. The rise in the fiscal ratio corresponded to the expansion of public expenditure, for the most part in three areas: health, education, and retirement. The rise of taxation reflects the construction of the modern social state, whose foundations Piketty traces to the principle of equality of rights as in the American Declaration of Independence (1776) and the French revolutionary Declaration of the Rights of Man and the Citizen (1789).

The author is perfectly well aware that the tax burden cannot increase any further. The rise between 1945 and 1980 was made possible by growth rates of per capita GDP and population that clearly cannot be repeated. The welfare state needs to be modernized; intervention on education and pensions, in particular, is unavoidable. Higher education is very costly, especially in the US and the UK, and does not produce social mobility. Upward social mobility is lowest in the United States, but it has diminished in Europe as well. Piketty criticizes the French grandes ècoles, to which, in practice, only the children of the rich have access. For pensions, population aging and slow economic growth will require the end of the "pay as you go" system. At the same time, the institution of a funded system will give rise to generational conflict, and the picture is further complicated by the presence of workers in different situations in terms of white-collar or blue-collar jobs, contribution regimes and career paths. Young people are uninformed about their prospective pensions, which will be quite small, and they should be given incentives to save more. 
In order to modernize the welfare state and reduce inequality, the tax system must be rethought, starting with the progressive income tax, which is threatened by fiscal competition between countries. Since 1980 the progressiveness of the system has been reduced in the US and the UK; and it is further threatened by the choice of many countries not to subject capital income to the progressive income tax. In France, for high incomes taxation is now actually regressive.

1.4.2 How to rethink taxation. The tax system has to be made progressive again, overcoming the current situation in which property is taxed less than earned income. An examination of income and inheritance taxes offers surprises. Until World War I they never went above 10 per cent, and did not begin to rise until later. The big surprise is that once progressive taxation was introduced, the highest marginal rates for both income and inheritances were in the US and Britain. Confiscatory taxation of the highest incomes was an American invention, confirming that for many years American society was more egalitarian than European society. From the 1930s to the 1970s the top marginal income tax rates in the US and the UK were between 80 and 90 per cent, and in both countries the marginal rate on major bequests reached 80 per cent.

This cultural climate changed around 1980 with the advent of Ronald Reagan and Margaret Thatcher. Britain and the US gradually lowered their top income tax rates, bringing them below those in effect in France and Germany. Of the possible explanations for the yoyo pattern of AngloSaxon wealth since 1930, Piketty selects the bargaining model (the fruit of a study of his own together with Emmanuel Saez and Stefanie Stantcheva). After World War II the executives of the large British and American corporations had no incentive to demand high salaries, because 80 per cent or more of any raise went to the State. But after 1980 we find a correlation between the decline in the top marginal rate and the increase in the income going to the top centile. According to the bargaining model these lower marginal tax rates gave executives the incentive to push for higher pay. The top managers convinced shareholders and boards of directors that their work needed to be better remunerated, among other things counting on the fact that "members of compensation committees were often chosen in a rather incestuous manner”. After 1980 there is no correlation, in the developed countries, between the decline in the tax rate on high incomes and the growth of productivity.

Piketty maintains that the optimal tax rate on high incomes in the industrial countries should be 80 per cent. This rate should apply to the top 1 or 0.5 per cent, i.e. incomes over $\$ 500,000$ or $\$ 1$ million, while incomes above $\$ 200,000$ should be subject to a tax of between 50 and 60 per cent. He is well aware that these proposals have little if no chance of adoption, given that President Obama has found it hard to raise the top marginal rate even to 40 per cent. The explanation is that 
the wealthiest Americans have essentially captured the political process (a thesis that it is near to the ideas of Krugman, 2007). There is an oligarchy comprising top executives, economists and politicians who defend their own high incomes, arguing that they are defending the general interest. Without some shock (unlikely), the United States risks being to the twenty-first century what Europe was to the Belle Epoque.

What Piketty advocates is a progressive global tax on capital. He describes this idea as Utopian, but adds that at the turn of the twentieth century the welfare state and the progressive income tax themselves were practically inconceivable. The economic area where such a tax would have the greatest chance of successful introduction is Europe. The tax would apply to the individual's net wealth. The rate might be zero for wealth up to $€ 1$ million, 1 per cent for $€ 1$ million to $€ 5$ million, and 2 per cent above $€ 5$ million. Piketty estimates that such a tax would be levied on 2.5 per cent of European Union citizens, generating revenues of as much as 2 per cent of GDP (€300 billion, given European GDP of $€ 15$ trillion).

The wealth tax would eventually replace local property taxes, which exist in various forms in some European countries. It would apply to all the individual's assets. It is essential that it be introduced in every country in Europe, including Switzerland, because otherwise financial wealth would simply shift to the countries that didn't have it. The US government notifies taxpayers yearly of the market value of the homes they own and requests payment of the real estate tax. European governments could follow this example, notifying their citizens of the market value of their assets (net of debt). To attain this objective, it is essential to collect data from banks - especially foreign banks - on individuals’ holdings of financial instruments.

The US gets data from foreign banks through the Foreign Account Tax Compliance Act (FATCA), passed in 2010 and now in the process of application. Piketty observes that FATCA is more advanced than what has been done in Europe for automatic exchange of bank data between countries. Europe, for instance, should institute automatic sanctions not only for banks but also for countries that do not compel their financial institutions to provide the requisite data. FATCA, like the less ambitious European directives, was created in order to gather data on assets held abroad, in order to detect income tax evaders. The same data could help in the institution of a capital tax.

Piketty does not see the prime reason for a capital tax as financing the welfare state. Rather, the purpose is to reduce inequality and enhance financial transparency. In order to improve our knowledge of the distribution of wealth, we must know who holds assets throughout the world. Automatic transmission of bank data would do away with surveys of household wealth, which the author describes as an "archaic method". Taxation of wealth instead of income has two 
justifications. First is the contributive justification: for the very rich, income is often an ill-defined concept that is hard to measure, whereas wealth gives more reliable information on the person's taxpaying capacity. Second, a wealth tax would strengthen the incentive to use capital more efficiently. Piketty acknowledges that in the design of a wealth tax important details must be specified: the precise tax schedule, the determination of the market value of individual assets, automatic transmission by banks of data on individuals' asset holdings, and the international exchange of these data.

1.4.3 On public debt. The public debt has begun to rise again in the developed countries, and Piketty maintains that an exceptional one-time tax on private wealth is the best way to reduce it. A capital tax is preferable both to default, which would generate financial instability and have negative redistributive effects, and to inflation, which is hard to control and has regressive redistributive effects to the disadvantage of the poorest. The continuation of austerity policies in Europe with accumulating primary budget surpluses, will reduce the debt very slowly - over more than twenty years - and entail cutting the social expenditure of the State.

A one-time capital tax should be more sharply progressive than an ordinary wealth tax. Lowering the average European debt/GDP ratio by 20 per cent could be done with a tax rate of zero on wealth up to $€ 1$ million, 10 per cent on wealth of $€ 1$ million to $€ 5$ million and 20 per cent above $€ 5$ million. Such a one-time tax could be accompanied by a "redemption fund" along the lines of that proposed in 2011 by a committee of economists named by the German government. The exceptional tax earmarked for debt reduction should apply to all household assets. The mistake made in Cyprus in 2013, when the European Commission intervened with the taxation of bank deposits alone, must not be repeated.

Piketty advocates the completion of European unification. A political and fiscal union must be achieved, with the pooling of national public debts and the constitution of a new parliamentary body to decide the European budget. Europe's public finance strategy should be openly discussed, unlike the discussions of the councils of heads of state and government or finance ministers. What is needed is a continental political authority capable of reasserting control over patrimonial capitalism and advancing the European social model in the twenty-first century.

\section{An assessment: how economists reacted to Piketty’ ideas.}

The reactions to Piketty’s book are practically countless, and he has parried them by responding that his work is at best merely an introduction to the study of capital in the new century. In this 
section I will deal with four issues: the ratio of wealth to income (2.1), distribution (2.2), economic policy proposals (2.3), and Piketty's style and polemics (2.4). Sub-section 2.5 sets out the conclusions.

2.1. The ratio of wealth to income. There are three principal questions here: Piketty's method, the causes of the rise in the ratio, and the judgment on wealth and patrimonial capitalism.

(i) Piketty's method. Piketty acknowledges that his book continues the pioneering work of Raymond Goldsmith on estimating income and wealth. Goldsmith's Study of Saving in the United States was a contribution to national accounting in the tradition of Wesley Clair Mitchell, Colin Clark, Simon Kuznets and Richard Stone. The literature on the connection of finance to growth subjected to criticism following the outbreak of the global financial crisis with the Lehman Brothers failure but still at the centre of the debate - takes off from the evidence in Goldsmith (1969) of a correlation between economic development and the size of the financial system. Piketty builds on Goldsmith (1985), with its reconstruction of the national balance sheets of twenty countries from the end of the eighteenth century to 1978. Goldsmith's idea is that capitalism has to be studied by examining the balance sheets of economic agents: households, firms, banks and other intermediaries, governments. Hicks (1935) had been explicit on this point: "We shall have to draw up a sort of generalized balance sheet, suitable for all individuals and institutions.” By this approach, capitalism consists essentially in accounts of stocks and flows.

Piketty comes to this approach after abandoning the training gotten in his youth. His position here could not be clearer: "The discipline of economics has yet to get over its childish passion for mathematics and for purely theoretical and often highly ideological speculation, at the expense of historical research and collaboration with the other social sciences." Capital in the Twenty-first Century is the epitome of this interdisciplinary manifesto. It is a work in economics, economic history, policy advocacy, and statistical reconstruction. Piketty (2014b) has spoken of a multidimensional approach transcending the traditional divisions between the social sciences. In addition to the book itself, Piketty has made available to scholars, online, another 900 pages of statistical time series and methodological discussion on income, wealth and other macroeconomic variables for eight countries: the US, Japan, Germany, the UK, France, Italy, Canada and Australia (http://piketty.pse.ens.fr/files/PikettyZucman2013Appendix.pdf). This material will allow to deepen the discussion on wealth measurement. For instance Weil (2015) has underlined the differences between Piketty's measurement of wealth at market values and the measurement of capital stock by the permanent inventory method. 
(ii) Why has the ratio of wealth to income risen? The chief finding, further developed by Piketty and Zucman (2014), is that the increase is due more to the accumulation of saving than to a rise in the prices of the real and financial assets in which households invest. The question is complicated, in view of the real estate and stock market bubbles in some countries both in the 1980s and 1990s and in the new millennium. Piketty mentions the "financialization" of economies as one of the reasons for the rising capital/income ratio but does not give much space to the issue. Yet capitalist economies differ from one another because households choose to invest in different financial assets; that is, in some countries the composition of financial assets may be tilted towards listed shares and insurance/pension instruments (as in the US and Britain), in others towards bank deposits and bonds (Italy and Japan; see Demirguc-Kunt and Levine, 2001, and Bruno, De Bonis and Silvestrini, 2012). Since the 1970s, everywhere households have increased the portion of financial instruments directly or indirectly bound up with the stock market and, except in Japan, decreased the resources held in the form of bank deposits (De Bonis, Fano and Sbano, 2013). The increase in financial wealth in relation to income may also have been influenced by the increased incidence of financial products valued at market prices. Another factor may have been the "equity puzzle", i.e. the fact that in some countries the long-term return to shares has been higher than that on risk-free bonds.

Some scholars have argued that a good part of the rise in the wealth/income ratio depends on trends in investment in houses and house prices (Bonnet, Bono, Chapelle and Wasmer, 2014; Rognlie, 2014; Knoll, Schularick and Steger, 2014). Our author has replied that he agrees with this thesis (Piketty, 2014b and 2014c). His book and its extraordinary database have made possible deeper investigation along the lines of inquiry he has laid out. The problem is to measure - country by country but with a common methodology - the portions of the rise in wealth that are due to saving, to higher financial asset prices, and to higher house prices.

Piketty recognizes that one factor in the rising wealth/income ratio has been the slow growth of the denominator. He remains pessimistic on this point, however, in the belief that population growth and technical progress will not duplicate the exceptional contribution that they made during the "golden age of growth" from 1950 to 1980. This forecast is akin to the secular stagnation hypothesis put forward by Summers (2014). Using national income, or disposable household income, as the scale variable for wealth has always raised methodological problems. However, it is worth underscoring that net per capita wealth too has increased in the industrial countries in recent years. In short, there is no doubt that wealth has increased greatly, and in all the advanced countries, but we still do not have a consensus on the determinants. Econometric analysis is hampered by the 
difficulty of discerning the causal nexus between wealth and the possible determinants; for two attempts, see Davies, Sandstrom, Shorrocks and Wolff (2011) and Zinni (2012).

(iii) Is wealth good or bad? Economists have opposing views on whether wealth plays a positive or a negative role. Up until World War II international comparisons tended to be based on wealth, not per capita income, as is standard practice today. Someone maintains that it was Americans who brought about the change in approach, inventing modern national accounts. International comparisons based on GDP showed the US to better advantage than comparisons of wealth. A similar attitude, some insinuate, was what guided President Sarkozy in forming the committee that produced the Stiglitz-Sen-Fitoussi report (2009), which says that wealth should be considered, jointly with income and consumption, in gauging individual well-being. There should be no need to reiterate that household wealth is significantly greater in France than in the US.

On the one hand, Piketty agrees with the report's thesis that the stocks of household assets and liabilities must be factored in when measuring well-being. On the other, he remains suspicious of the accumulation of wealth. He seems to underestimate its importance as a buffer to cushion health, old age, or labour market shocks. With the crisis of pension systems, household investment in insurance and pension funds has increased everywhere. This is a positive development, and one that will strengthen in the future. What is more, the spread of home ownership to the less affluent has been another aspect of the stabilization of capitalism (regardless of property bubbles, which in any case occurred even in the nineteenth century, when home ownership was rare). Piketty's critical judgment of patrimonial capitalism and the development of the middle class would is exaggerated. Next, however, we must discuss the distribution of income and wealth, given that in Piketty's view patrimonial capitalism is intrinsically bound up with growing inequality.

2.2. Distribution. In the introduction, the author observes that the book is based on fifteen years of research, beginning in 1998. His first book on distribution was written in French in 2001 and was followed by a series of works in English. The author acknowledges his debt to Anthony Atkinson and Emmanuel Saez, co-authors of several contributions (e.g. Piketty and Saez, 2003; Atkinson and Piketty, 2007 and 2010). Piketty and Saez gained fame, in American political debate as well, as the first to study the rapid rise in the incomes of the "top 1 per cent”. An astonishing source, the World Top Income Database, is at once the basis and the product of these studies (http://topincomes.parisschoolofeconomics.eu; see The Economist, 2014a).

Six issues in particular warrant discussion: the relationship between distribution and technology, the theory of superstars, the question of relative vs. absolute distribution, the relationship between 
the rate of return to capital and the growth rate of the economy, the statistics on the inequality of wealth distribution, and the link between increasing income inequality and the US financial crisis.

(i) The distribution of income does not depend on technological developments. The book's central message is that income distribution is not determined by technological factors, gauged as the marginal productivity of the individual worker, but instead depends on institutional and cultural variables, which can be affected by economic policy measures. And in fact it is difficult indeed to maintain that CEOs' compensation is linked to their marginal productivity, when in large corporations the concept itself is impossible to define. Shell's CEO has been quoted as saying "If I had been paid half as much I wouldn't have run the company any worse and if I had been paid twice as much I wouldn't have run it any better” (The Guardian, 19 August 2014, quoted in Atkinson, 2014).

In large corporations, very often technology is common to all the rich countries (think of carmakers), but the share of income going to the top 1 per cent or 10 per cent differs. The differences in top incomes between the US and Europe depend on other variables, such as taxes, public attitudes towards very high incomes, the social norms that affect people's views of trade unions and the functioning of markets (Brandolini, 2010), labour market mechanisms (for example, individual wage-setting), the power of managers and poor corporate governance, and the incidence of capital incomes (for a summary, see Alvaredo, Atkinson, Piketty and Saez, 2013).

A good many articles have noted that in the US and the UK the rise in income inequality has been correlated with the increase in average firm size. We know that large firms are more productive than small, and that the former pay higher salaries. But these higher wages are not evenly distributed among all workers (Mueller, Simintzi and Quimet, 2015). Salary differences increase with firm size. The end result is determined by the widening gap between the highest salaries and those in the middle and lower ranges of the distribution (see the summary in The Economist, 2015a). But average firm size has been constant or even decreasing in countries like Sweden, Denmark, Greece, Italy and Portugal. We still need to investigate the existence of a relationship between the top income share and the size of firms. To give just one example, firms are larger in Germany than in Britain (an average of 12 workers against 10) but the share of income going to the top 1 per cent is lower.

(ii) The very rich are not just entertainment superstars. Piketty is not against inequalities per se, only unjustified inequalities. The data show that the very rich are not mostly sports or show business superstars. That thesis (see Rose, 1981) was put forward to justify the increased income share of the top 1 per cent in some countries. Thanks to television, an enormous number of 
consumers now have access to entertainment, which comprises sports, movies and music. For the 2009-10 season, for instance, Cristiano Ronaldo's salary was 15 times higher, in real terms, than Pelé earned in 1960 (Porter, 2010). Millions of people are willing to pay to see a match featuring Ronaldo on TV, which was not possible in Pelé's day. It is this innovation - not the marginal productivity of the two players' goals - that explains the difference in earnings.

Piketty's point is that athletes and show business stars - whose performances we can purchase on TV - make up a relatively small part (around 5 per cent) of the richest 1 per cent of the population; managers and people with inherited wealth predominate. Kaplan and Rauh (2013) and Mankiw (2013) have replied that in the United States, superstars include highly talented managers not heirs - who had access to high-quality education in their youth and have applied their talents in three fields in particular: technology, finance and retailing. Bell and Van Reenen (2013) show that since 1999 British bankers' bonuses have accounted for practically two-thirds of the rise in the income share going to the top 1 per cent in the United Kingdom. Paul Krugman (2014), in praising Piketty's “truly superb book," had only one criticism, namely its failure to go more deeply into the high salaries in the financial industry, which Krugman linked to the deregulation that preceded the crisis. Prior to the crisis, the high salaries of CEOs, investment bankers, hedge fund operators and the heads of other intermediaries appeared to be a rational manifestation of the market, rewarding the financial superstars. Regulators did not intervene, on the theory that intermediaries had to be free to set the prices of their products and their inputs, hence including executive compensation. The crisis has worked a cultural transformation, as the European Commission has made proposals and supervisors have set limits on executive pay to reduce the incentives for excessive risk-taking. Piketty, however, calls for taxation of all top incomes, in that he does not view the boom of financial capitalism as the chief economic development in the advanced countries since the 1970s.

(iii) Relative vs. absolute distribution. Piketty focuses on the relative distribution of income and wealth, not on absolute poverty. This approach is contested by those who argue that since the nineteenth century capitalism has multiplied per capita GDP thirtyfold in the rich countries, improving the living conditions of the poorest (see McCloskey, 2014). This is the traditional position that the State should act to reduce the number of poor people - absolute poverty - but not to affect relative income distribution.

One gets the impression that Piketty avoids this issue because unlike the distribution of income, absolute poverty is an area in which a number of initiatives are in fact under way. In recent years extreme poverty has been reduced worldwide, thanks above all to the exceptionally rapid economic growth of China and India. Between 1990 and 2011 the share of people living below the world 
poverty line (\$1.25 a day at 2005 purchasing power parities) fell from 36 to 14 per cent of the global population (from 1.9 billion to 1 billion individuals), five years ahead of the UN Millennium Development Goals target. In 2013 the World Bank set two new objectives: ending extreme poverty (reducing it to under 3 per cent of the world population by 2030) and promoting shared prosperity, defined as fostering income growth for those below the $40^{\text {th }}$ percentile in every country. And Europe's strategy for 2020 includes a European platform against poverty and exclusion. The Commission proposes to help EU countries lift 20 million people out of poverty and exclusion by that date.

In short, there is no doubt concerning the aim of a further reduction in absolute poverty. What is contentious is the question of relative distribution of income. On this point, Piketty has been reproached not only by McCloskey but also “from the left.” Soskice (2014) observed that the book ignores the poorest 10 per cent in the developed countries, whose conditions have worsened owing to the rise in unemployment and precarious employment. Piketty (2014) readily responded that this is an important issue, as is further inquiry into gender-based wage differences.

A key question - one that Krugman in particular has stressed - is the influence that the 1 per cent wield over the political process in the United States. Here, let us simply recall the opinion of Angus Deaton, who has argued that the increasing inequality of income constitutes a problem for American democracy, which threatens to turn into a plutocracy. ${ }^{2}$ He agrees with the observation attributed to Supreme Court justice Louis Brandeis (1856-1941), namely that "We must make our choice. We may have democracy, or we may have great wealth concentrated in the hands of a few, but we can’t have both.”

(iv) Rate of return to capital and growth rate. As I noted above, Piketty sets out graphs showing that since the year 1 the pre-tax return to capital has been higher than the rate of economic growth. And even the after-tax return has outstripped GDP growth, save for the exceptional period of the twentieth century. He predicts, furthermore, that in the twenty-first and twenty-second centuries the after-tax return to capital will again be higher than the rate of income growth.

This empirical evidence has been criticized, on the grounds that the constant accumulation of capital should lead to diminishing returns. The point is that Piketty is looking at the return to total wealth, both financial and real (see also The Economist, 2014b). From 1 A.D. to 1900, the net yield of wealth - consisting almost entirely of land - held constant at between 4 and 5 per cent. That

\footnotetext{
2 "There is a danger that rapid growth of top incomes can become self-reinforcing through the political access that money can bring ... If democracy becomes a plutocracy, those who are not rich are effectively disenfranchised.” Deaton (2013).
} 
would appear to have been the case during the Roman Empire (see Goldsmith, 1984, and Scheidel and Friesen, 2009, cited by Milanovic, 2014) and the centuries following. French and English novels of the nineteenth century also refer to a yield on landed wealth or public bonds of around 5 per cent. Over this period inflation was near zero and real economic growth negligible. This persistent gap between $r$ and $g$ thus explains the great inequality in the distribution of wealth up until World War I.

Over the period of the two world wars of the last century, $r$ (net of taxes) collapsed, falling below the growth rate and so producing the attenuation of the inequality in the distribution of wealth. Beginning in the 1970s the growing financialization of capitalism and heightened international competition for capital helped to push $r$ back up above $g$, causing a new increase in inequality of wealth.

Piketty produces evidence from France and Britain that $r$ has almost always been higher than $g$, speaking of this as "a historical fact, not a logical necessity." Of course, it is in no way established that the yield of wealth will always be higher than the growth rate. For example, today's low interest rates could refute Piketty's thesis, although the returns to the stock market and houses could corroborate it, given continuing low growth rates. Since the publication of the book, the author has de-emphasized the $r / g$ ratio, repeating that other forces also play a role in the increasing inequality of wealth (Piketty, 2015).

Acemoglu and Robinson (2015) have shown that the correlation between the $r$ - $g$ differential and the income share of the top 1 per cent is negative or statistically insignificant and inferred that there is no link between a widening gap and growing income inequality. Piketty (2015) has replied that the inequality of income depends above all on the inequality of labor income, which is unaffected by the gap between $r$ and $g$. The proper correlation, he maintains, is that between the $r-g$ differential and the inequality of wealth, but the necessary data are available for only a few countries.

(v) The statistics on the distribution of wealth. The Financial Times has questioned the existence of a rising trend in wealth inequality over the past forty years (Giles, 2014), and Piketty has rebutted the criticism (Piketty, 2014). For France and Spain, the differences between the data of the Financial Times and those of Piketty are negligible. For the United Kingdom, the newspaper uses surveys, which are flawed by a low response rate and the classical problem of underreporting of assets. Piketty uses tax returns, which are more reliable. For the United States, Saez and Zucman (2014), using new statistics, have shown that the wealth inequality is actually greater than Piketty reported: the share of wealth held by the top 0.1 per cent rose from 7 per cent in 1979 to 22 per cent in 2012, practically the same as in 1929. Piketty himself had already emphasized the difficulty of 
measuring inequality of wealth by comparison with the progress made in gauging income inequality. His aim for the future is to convert the World Top Incomes Database into a World Wealth and Income Database and compile these statistics for the thirty countries it now covers. To give just one example, today's more equal wealth distribution by comparison with the end of the nineteenth century could depend on more widespread home ownership. In fact, wealth distribution is more unequal in countries like the US and Germany, where fewer households (under 50 per cent) own their homes.

(vi) Did growing inequality cause the financial crisis? Though Piketty treats this question almost just in passing, devoting only a few pages to it, his thesis that the US financial crisis of 2008 was bound up with the increase income inequality is unconvincing. Going by this interpretation, politicians and regulators encouraged the expansion of credit to households, chiefly for home purchase, as a counterweight to the growing inequality of income. But sub-prime mortgages constituted a very small portion of total mortgage lending. It was other causal factors - international macroeconomic imbalances, the malfunctioning of interbank markets, the opacity of the securitization market, banks' excessive leverage and illiquidity, the slowness of regulators - that turned the minor shock of sub-prime defaults into the Great Recession (see Blanchard, 2009; Brunnermeir, 2009; Gorton and Metrick, 2012; Lo, 2012; Shleifer and Vishny, 2011). Income inequality is still pronounced in the United States today, but it is hard to see it as a threat to financial stability.

2.3. Piketty and economic policy. Part Four, on the regulation of capital, is the section of Piketty's work that has prompted the most intense polemics. It treats four main themes: the reform of the social state, income taxation, the taxation of wealth, and the European public debt.

(i) The social state. Piketty does not favour the indiscriminate expansion of public spending. On the contrary, he argues that the State must concentrate its action in a few selected sectors, education above all. On this point there is broad consensus both in the United States and in Europe. The American educational model has produced excellent results in academic research, but social mobility has not been fostered by access to higher education, which instead has stiffened the obstacles already in place (The Economist, 2015). The gap in university degrees between rich and poor is widening. College enrollment rates have doubled over the past twenty years, but the US has failed to offer equity in access to higher education. Piketty (2014c) has recalled that the average income of the parents whose children attend Harvard corresponds to the top 2 per cent (compared with 9 per cent at the prestigious Sciences-Po in Paris). Robert Putnam's latest book confirms that 
in the US the probability of getting a university degree is higher for students from more affluent families.

National university systems in Europe differ from one another, but they all share such major features as cost control, higher fees for students from wealthier families, and measurement of the results produced by universities vis-à-vis high schools. While different countries have different standards for evaluating higher education, the OECD has undertaken its Assessment of Higher Education Learning Outcomes project, whose ambition is to become, for universities, what the PISA test is for middle and high schools. Piketty does not challenge prevailing views on these issues, save in his insistence on learning as a value per se rather than on its yield in economic terms.

(ii) Income taxation. Piketty's argument for raising the marginal tax rate on the top incomes is less persuasive. Today there appears to be little chance of pushing those rates back up to the levels prevailing before Reagan and Thatcher. In a number of countries it is considered unjust to impose marginal rates above some given threshold: that is, it is felt that the State has no right to raise tax rates too far. These countries also maintain that fiscal competition between countries should be encouraged.

A short account of recent developments in the United Kingdom is illuminating. In April 2010, in response to the financial crisis, the top income tax rate was raised temporarily to 50 per cent (HMRC, 2012; on the connection between tax system and crisis, see Ceriani, Manestra, Ricotti, Sanelli and Zangari 2011). Until then, the top rate had not changed in over thirty years. The government expected the measure to generate additional revenue of $£ 2.5$ billion, but in practice the new rate produced significant tax elusion, as by deferring the receipt of a portion of individual incomes to after 2010. Estimates are uncertain, but the proceeds of the measure may have amounted to just $£ 1$ billion (indeed, it may actually have resulted in a loss of revenue). HMRC (2012) underscores the risk of high taxes for capital inflows and outflows. High taxes make the UK less attractive for undertaking, financing and expanding business activities. Following this official assessment, in April 2013 the top tax rate was lowered to 45 per cent. Opponents of this move argued that the 50 per cent rate should have been kept, because income cannot be deferred forever (Bell and Van Reenen, 2013).

(iii) Wealth taxation. In the abstract, Piketty's idea of a uniform tax on wealth is more convincing. This proposal is in line with the recurrent call to lower income taxes and raise capital taxes. Piketty suggests a tax base consisting of individuals' total net wealth. In fact it is hard to see the justification for diversified taxation of real and financial assets, net of debt. The point is that a progressive tax on wealth or capital would have to be imposed, as Piketty observes, not only in 
Europe but worldwide. Otherwise, financial assets would be shifted outside Europe, so that in the end only real assets would be taxed. Distortions and additional inequalities would be created, because tax evasion and elusion are easier for the wealthy.

Piketty is motivated by a sincere interest in enhancing transparency on holdings of financial and real assets. Here, it is worth highlighting the progress made both in Europe and in the OECD generally. Europe took the first step in 2005 with the institution of automatic data exchange, limited to financial income in the form of interest. As Piketty notes, the American Foreign Account Tax Compliance Act is considerably more ambitious, requiring reporting to the Internal Revenue Service (IRS) of data on financial assets held abroad by US citizens. The European Union is now taking the same path, following the approval of the OECD's 2014 Common Reporting Standard, which calls for the transmission of the data on an individual's financial wealth held abroad to his or her state of residence. Outside the European Union, the adoption of the OECD standard will bring automatic data exchange in 2017 or 2018, involving 101 countries, including most off-shore financial centres ${ }^{3}$. These initiatives will be further reinforced by the new mandate given to the OECD by the G20 after the outbreak of the "Panama Papers" tax case to insure availability of information on the beneficial ownership of companies ${ }^{4}$.

In conclusion, we will not get the progressive global wealth tax that Piketty advocates, but a number of initiatives are already increasing our knowledge of assets held in foreign countries, potentially narrowing the scope for tax evasion (for a more skeptical view of the end of bank secrecy and the “crackdown” on tax havens, see Johannesen and Zucman (2014) and The Economist 2015c).

(iv) Public debt reduction. The idea of a one-off tax on capital to lower the public debt is unconvincing. Within the euro area, debt adjustment will be a protracted process, depending on the return to a satisfactory growth rate, primary budget surpluses, and inflation of around 2 per cent (and, in some countries, debt restructuring). Other proposals foresee a gradual process of reimbursement, where possible earmarking of a designated tax should be distributed over time as well (see, e.g., German Council of Economic Experts, 2012). An extraordinary capital tax would

\footnotetext{
${ }^{3}$ OECD, "Bahrain, Lebanon, Nauru, Panama and Vanuatu have now committed to the international standard of automatic exchange of financial account information to tackle tax evasion and avoidance”, Press Release, May 11, 2016.

${ }^{4}$ On April 3, 2016 the International Consortium of Investigative Journalists published the results of an enquiry that shed light on the activity of a Panamian law firm (Mossack Fonseca) offering services aimed at establishing opaque offshore companies in Panama and other tax havens to hide assets held by residents of all countries. See Rusbridger (2016).
} 
produce distortions and undermine taxpayers' already shaky trust in government. On the other hand, Piketty's call for the completion of a European political union is totally opportune (on the establishment of a supranational fiscal capacity, see Balassone, Momigliano, Romanelli and Tommasino, 2014).

To sum up, Piketty's policy proposals have been subjected to sharper criticism than his other ideas. As I see it, he rightly notes market failures but underplays the risk of government failures. Yet there is no lack of other authors taking similar positions. For example, Atkinson (2014) has proposed a return to progressive taxation with a rate of 65 per cent on the top 1 per cent of incomes, a corporate code of ethics for executive compensation to limit the gap between the highest and the lowest salaries, a higher tax on investment income, an annual wealth tax, and a tax on bequests and donations as part of wealth or personal income taxes.

Any idea for reducing inequalities implies considerations of equity. This is the sphere of political philosophy. For that matter, Piketty holds that the foundations of the social state - the notion of fundamental rights and the extension of material well-being to the greatest possible number of citizens - are consistent with the philosophy of John Rawls and Amartya Sen. Citing John Stuart Mill and the liberal tradition, in his "Restatement" of Justice as Fairness Rawls reaffirmed the need for the progressive taxation of incomes and of bequests and donations. The purpose is to foster more equal distribution and prevent the accumulation of large fortunes, which are seen as opposed to the concepts of justice, political liberty and equality of opportunity (Rawls, 2001). But there is no ignoring the fact that, quite apart from practical problems of application, there are also diametrically opposed opinions on the taxation of wealth and bequests (see Auerbach and Hasseth, 2015).

2.4. Piketty as writer and as polemicist. Kindle tracks the last page opened in the books downloaded. The mathematician Jordan Ellenberg has calculated that on average readers of Capital in the Twenty-first Century stop at page 26, about the end of the introduction. By his estimate, just 40,000 readers have actually read the entire volume. We are free to reject this assessment, of course, but we cannot deny that the book is not well edited. Some concepts are reiterated far too many times. Better editing would have made for more orderly presentation of topics and arguments and eliminated needless repetition, possibly producing a shorter and more streamlined work.

Nonetheless, the work is a pleasure to read. For one thing, in our age of storytelling Piketty has filled the volume with references to literature (Austen, Balzac, James, Tolstoy), movies (The Aristocats, Titanic, Barry Lyndon, Django Unchained) and TV shows (Damages, Dirty Sexy 
Money, Mad Men). The message is clear: writers and directors have been better than economists and historians at describing the importance of real estate and financial fortunes and the social mechanisms they spawn, such as rents and inheritance.

Second, the book shuns the "politically correct" and abounds with pointed irony. Piketty has unkind words to say about many people. Let us cite examples relating to ten of his favourite targets.

- Simon Kuznets offered a "fairy tale" about the trend to greater equality in the distribution of income, a thesis that Piketty described as a product of the Cold War (but here we have a love-hate relationship, because Piketty also notes that research into differences in individual income began with Kuznets’ 1953 work).

- Robert Solow posited a balanced growth path that has never actually existed; just as there has never been a constant capital/income ratio.

- Thomas Jefferson, one of the founding fathers of American democracy, owned 600 slaves and had an ambiguous attitude towards slavery as an institution.

- Counting human capital as part of individual wealth makes no sense, at least now that slavery has been abolished. Capital is an asset that can be exchanged in the market and that carries a determinate price. The emphasis on human capital by Gary Becker, the World Bank and other institutions is uncalled for.

- The Gini Index provides an abstract, sterile account of inequality that makes it impossible for individuals to grasp their place in the income hierarchy. Instead, distribution should be studied by distinguishing the various population strata, and in particular the top 10 per cent

- Vilfredo Pareto was an admirer of Mussolini and maintained the thesis of constant income distribution shares.

- Franco Modigliani's life cycle theory offers a reassuring vision of a society in which individuals die with no bequests. In the 1950s sociologists like Talcott Parsons took advantage of this thesis to portray the United States as a managerial middle class society in which inheritance had no role.

- Household budget surveys should be dropped as a source of data: they are available only as of the 1960s or '70s and they suffer from problems of underreporting and misreporting. Tax returns furnish more accurate, long-run data on the distribution of income and wealth.

- The return to capital consists of three components: work, pure luck, and theft ("Property sometimes begins with theft, and the arbitrary return on capital can easily perpetuate the initial crime"; readers can hardly fail to note the allusion to Proudhon's "What is Property?" published in 1840). 
- American family and charitable foundations often serve to avoid taxes while keeping control of the assets in the hands of the family, and it is often hard to distinguish the private from the genuinely public uses of these entities.

This list could go on and on. Some of these criticisms are uncalled for, some overdone, some apt - in any case, the polemical style makes for a livelier text. And Piketty can claim another merit, namely obliging all of us to question concepts that we take for granted. Economics is more insular and more hierarchical than other disciplines (Fourcade, Ollion and Algan, 2015). Let's hope for an increasingly frank and open discussion.

Many years ago Anthony Atkinson observed that income distribution had grown more unequal starting in the 1980s. But there is no question that until Piketty's work most economists agreed with Robert Lucas, who said "Of the tendencies that are harmful to sound economics, the most seductive, and in my opinion the most poisonous, is to focus on questions of distribution.” Martin Feldstein is of the same opinion. This may still be the prevailing attitude within the profession, but certainly not among the readers of Capital in the Twenty-first Century, whose success has been due in part to its publication in the midst of the worst recession since World War II. When economic growth dwindles, interest in how the smaller pie is shared increases and greater attention is paid to the top 1 per cent.

\subsection{A final assessment.}

Thomas Piketty's work is an old-fashioned book. It is rare, nowadays, for an economist to publish a book nearly 700 pages long in English (about 950 in the French original). One naturally associates such a book with other works far back in time, like The Wealth of Nations or The General Theory. Just as rare is it to see an economist tackle, all at once, such vast issues as household wealth, economic relations between the rich and the emerging countries, inequality and distribution, taxation, and the public debt. These are topics that are usually analyzed singly, and in reference to a single country and a brief period of time. Piketty is old-fashioned in examining these issues in an analysis that embraces a large number of countries and with extremely long time series.. This “old-fashioned” approach is one of the book’s greatest strengths.

In recent years, a good many scholars have offered interpretations of the differences between capitalist economies. The group coordinated by Andrei Shleifer holds that a country's degree of financial development depends on its legal tradition (Anglo-Saxon, French, German, or Scandinavian). Rajan and Zingales see the rise of competitive markets, especially well developed 
financial markets, as the prerequisite for a capitalism not dominated by elites. Acemoglu and Robinson maintain that a country's success or failure depends on whether it has good or bad institutions. From a longer-run perspective, Diamond has argued that national development - the fate of human societies - can be traced to military strength, steel and diseases.

Piketty's sweeping fresco sets forth and develops many of these themes: the comparative approach, focusing mainly on the rich but extending also to the emerging countries; the long-term view, the French school's "longue durée"; the role he ascribes to public institutions in shaping capitalist systems, in particular labor market rules, education systems and fiscal systems; his attention to both the real economy and to financial structures; his combined use of economic theory, economic history, literature, political sociology and an unparalleled statistical apparatus (one possible comparison is with the reconstructions of Angus Maddison).

Piketty's special merit lies in forcing us to debate the great questions, now a need that enjoys a broad consensus (see Guldi and Armitage, 2014), even among his most severe critics. Without his contribution no one would have moved economic discussion onto the terrain of the relations between wealth, income and their distribution. Nor would we have the data necessary to falsify his conclusions. As we have seen, not all of his responses are immune to criticism. But the value added of any worthwhile scientific research consists in asking the right questions, and there is no doubt that in this Thomas Piketty has attained the objective in full. 


\section{References}

Acemoglu D. and J. A. Robinson (2015), The Rise and Decline of General Laws of Capitalism, Journal of Economic Perspectives, 29, 1, 3-28.

Alvaredo F., A. B. Atkinson, T. Piketty and E. Saez (2013), The Top 1 Percent in International and Historical Perspective, Journal of Economic Perspectives, 27, 3, 3-20.

Atkinson A. B. e T. Piketty (2007), Top Incomes over the Twentieth Century: A Contrast between Continental-European and English-Speaking Countries, Oxford University Press.

Atkinson A. B. e T. Piketty (2010), Top incomes: A Global Perspective, Oxford University Press.

Atkinson A. B. (2014) After Piketty?, The British Journal of Sociology, 65, 4, 619-638.

Auerbach A. J. e K. Hassett (2015), Capital Taxation in the Twenty-First Century, American Economic Review, 105, 5, 38-42.

Balassone F., S. Momigliano, M. Romanelli, e P. Tommasino (2014), Just round the corner? Pros, cons, and implementation issues of a fiscal union for the euro area, Bank of Italy, Occasional papers, n. 245, November.

Bell B. e J. Van Reenen (2013), Bankers and their Bonuses, The Economic Journal, 124, febbraio, $1-21$.

Bertrand M. e S. Mullainathan (2001), Are CEOs Rewarded for Luck? The Ones without Principals Are, Quarterly Journal of Economics, 3, 901-932.

Blanchard O. (2009), The Crisis: Basic Mechanisms, and Appropriate Policies, IMF Working paper, April, n. 80.

Bonnet O., P.-H. Bono, G. Chapelle, E. Wasmer (2014), Does housing capital contribute to inequality? A comment on Thomas Piketty's Capital in the 21st Century, Sciences Po Economics Discussion Papers, n. 7.

Brandolini A. (2010), Political Economy and the Mechanism of Politics, Politics\&Society, 38, 212226.

Brunnermeier M. K. (2009), Deciphering the Liquidity and Credit Crunch 2007-2008, Journal of Economic Perspectives, n. 1, 77-100 
Bruno G., R. De Bonis e A. Silvestrini (2012), Do Financial Systems Converge? New Evidence from Financial Assets in OECD Countries, Journal of Comparative Economics, 40, 1, febbraio, 141-155.

Ceriani V., S. Manestra, G. Ricotti, A. Sanelli e E. Zangari (2011), The tax system and the financial crisis, Bank of Italy, Occasional Paper, n. 85, January.

Davies J. B., S. Sandstrom, A. Shorrocks e E. Wolff (2011), The Level and Distribution of Global Household Wealth, The Economic Journal, marzo, 223-254.

Deaton A. (2013), The Great Escape. Health, Wealth, and the Origins of Inequality, Princeton University Press.

De Bonis R. e A. Pozzolo (2012) (a cura di), The Financial Systems of Industrial Countries. Evidence from Financial Accounts, Springer.

De Bonis R., D. Fano and T. Sbano (2013), Household aggregate wealth in the main OECD countries from 1980 to 2011: what do the data tell us?, Bank of Italy, Occasional Paper, n. 160, April.

Demirguc-Kunt A. and R. Levine (2001), Financial Structure and Economic Growth, The MIT Press.

Diamond P. A. (2016), Addressing the forces driving inequality in the United States, Contemporary Economic Policy, 34 (3), 403-411.

Ellenberg J. (2014), The Summer's Most Unread Book Is..., The Wall Street Journal, 3 luglio.

Fourcade M., E. Ollion e Y. Algan (2015), The Superiority of Economists, Journal of Economic Perspectives, 29, 1, 89-114.

German Council of Economic Experts (2012), The European Redemption Pact: An Illustrative Guide, WP 02, February.

Giles C. (2014), Data problems with Capital in the 21st Century, Financial Times, 23 maggio.

Goldin C. D. e L. F. Katz (2010), The Race between Education and Technology: The Evolution of the U.S. Educational Wage Differentials, 1890-2005, Cambridge MA.

Goldsmith R. W. (1969), Financial Structure and Development, Yale University Press.

Goldsmith R. W. (1985), Comparative National Balance Sheets, A Study of Twenty Countries 1688-1978, The University of Chicago Press. 
Gorton G. B. e A. Metrick (2012), Getting-up to speed on the financial crisis: a one-week-endreader’s guide, NBER working paper n. 17778.

Guldi J. e D. Armitage (2014), The History Manifesto, Cambridge University Press (http://historymanifesto.cambridge.org/files/1114/2314/8679/historymanifesto.pdf).

Hicks J. R. (1935), A Suggestion for Simplifying the Theory of Money, Economica, 2, 5, 1-19

HMRC (2012), The Exchequer effect of the 50 per cent additional rate of income tax, Her Majesty’s Revenue and Customs.

Johannesen N. e G. Zucman (2014), The End of Bank Secrecy? An Evaluation of the G20 Tax Haven Crackdown, American Economic Journal: Economic Policy, 6, 1, 65-91.

Lo A. L. (2012), Reading About the Financial Crisis: A Twenty-One-Book Review, Journal of Economic Literature, n. 1, 151-178.

Lucas R. E. (2004), The Industrial Revolution: Past and Future, Federal Reserve Bank of Minneapolis, maggio, 1-15.

Kaplan S. N. e J. Rauh (2013), It's the market: The Broad-Based Rise in the Return to Top Talent, Journal of Economic Perspectives, 27, 3, 35-56.

Knoll K., M. Schularick e M. Steger (2014), No Price Like Home: Global House Prices, 1870-2012, CEPR Discussion Paper n. 10166.

Krugman P. (2007), The Conscience of a Liberal, W.W. Norton.

Krugman P. (2014), Why We're in a New Gilded Age, The New York Times, 8 maggio.

Kuznets S. (1953), Shares of Upper Income Groups in Income and Savings, Cambridge, Ma, NBER.

Kuznets S. (1955), Economic Growth and Income Inequality, American Economic Review, 45, 1, $1-28$.

Mankiw N. G. (2013), Defending the One Percent, Journal of Economic Perspectives, 27, 3, 21-34.

McCloskey D. N. (2014), Measured, Unmeasured, Mismeasured and Unjustified Pessimism: A Review Essay of Thomas Piketty's Capitalism in the Twentieth Century, mimeo, forthcoming in Erasmus Journal of Philosophy and Economics

Milanovic B. (2014), The Return of “Patrimonial Capitalism”: A Review of Thomas Piketty’s Capital in the Twenty-First Century, Journal of Economic Literature, 52(2), 519-534. 
Mirrlees J. A. (2016), Capital and inequality, Contemporary Economic Policy, 34 (3), 399-402.

Mueller H., E. Simintzi and P. Quimet (2015), Wage inequality and firm growth, LIS Working Paper 632, marzo.

Ng Y.-K. (2016), Separating efficiency and equality, automation, and Pikett's theory of increasing capital share, Contemporary Economic Policy, 34 (3), 396-398.

Pellegrini V. e E. Tosti (2012), In search of lost capital: an estimation of undeclared portfolio assets, Bank of Italy, Occasional Paper, n. 131, September.

Piketty T. (2014a), Capital in the Twenty-First Century, Harvard University Press.

Piketty T. (2014b), Capital in the Twenty-First Century: a multidimensional approach to the history of capital and social classes, The British Journal of Sociology, volume 65, 4, 736-747.

Piketty T. (2014c), Les métamorphoses du capital: reflections autour du Capital au XXIe siècle, Revue dé l’OFCE, 137, 9-29.

Piketty T. (2014d), Technical appendix of the book "Capital in the twenty-first century". Appendix to chapter 10. Inequality of Capital Ownership. Addendum: Response to FT, 28 maggio.

Piketty T. (2015a), Putting Distribution Back at the Center of Economics: Reflections on Capital in the Twenty-First Century, Journal of Economic Perspectives, 29, 1, 67-88.

Piketty T. e E. Saez (2003), Income Inequality in the United States, 1913-1998, The Quarterly Journal of Economics, CXVIII, febbraio, 1-39.

Piketty T., E. Saez, e S. Stantcheva (2014), Optimal Taxation of Top Labor Incomes: A Tale of Three Elasticities, American Economic Journal: Economic Policy, 6(1), 230-71.

Piketty T. e G. Zucman (2014), Capital is back: wealth-income ratios in rich countries 1700-2010, Quarterly Economic Journal, 129, 3, 1155-1210.

Porter E. (2010), How Superstars’ Pay Stifles Everyone Else, New York Times, December 25.

Putnam R. (2015), Our Kids: The American Dream in Crisis, Simon \& Schuster.

Rawls J. (2002), Giustizia come equità. Una riformulazione, Feltrinelli, Milano.

Rognlie M. (2014), A note on Piketty and diminishing returns to capital, mimeo, 15 giugno.

Rosen S. (1981), The Economics of Superstars, The American Economic Review, 71, 5, 845-858.

Rusbridger A. (2016), Panama: The Hidden Trillions, The New York Review of Books, 27 October. 
Saez E. e G. Zucman (2014), Wealth Inequality in the United States since 1913: Evidence from Capitalized Income Tax Data, NBER Working Paper 20625, ottobre.

Scheidel W. e S. J. Friesen (2009), The Size of the Economy and the Distribution of Income in the Roman Empire, The Journal of Roman Studies, volume 99, novembre, 61-91.

Shleifer A. e R. Vishny (2011), Fire Sales in Finance and Macroeconomics, Journal of Economic Perspectives, 25, 1, 29-48.

Solow R. (2014), Thomas Piketty Is Right. Everything you need to know about "Capital in the Twenty-First Century”, New Republic, 22 aprile.

Soskice S. (2014), Capital in the twenty-first century: a critique, The British Journal of Sociology, volume 65, 4, 650-666.

Stiglitz E. S., A. Sen e J. P. Fitoussi (2009), Report by the Commission on the Measurement of Economic Performance and Social Progress.

The Economist (2014a), Picking holes in Piketty, 31 maggio.

The Economist (2014b), Bigger than Marx, 3 maggio.

The Economist (2015), Special Report. Universities. Excellence v equity, 28 marzo.

The Economist (2015a), The bigger, the less fair, 14 marzo.

The Economist (2015b), Follow the money, 7 febbraio.

The Economist (2015c), Leaks on tap, 28 febbraio.

Weil D. N. (2015), Capital and Wealth in the Twenty-First Century, American Economic Review, 105(5), 34-37.

Zinni M. B. (2012), Essays in Household Financial Balance Sheets, Ph. Thesis, Tor Vergata University.

Zucman G. (2013), The Missing Wealth of Nations: Are Europe and the U.S. Net Debtors or Net Creditors?, Quarterly Journal of Economics, 1321-1364. 